\title{
Has Empowerment Program Been Appropriate for the Need of Fisheries Business Player? : Case Study in Lampung Province, Indonesia
}

\author{
Irwan Effendi; Helvi Yanfika*; Sumaryo; Indah Listiana; Abdul Mutolib; Ali Rahmat \\ Faculty of Agriculture, University of Lampung, Bandar Lampung, Indonesia \\ *Helviyanfika@yahoo.co.id
}

http://dx.doi.org/10.18415/ijmmu.v6i4.982

\begin{abstract}
This study analyzed the appropriateness of empowerment program regarding the needs of traditional fish processors. This study applied the descriptive qualitative method using the model of Context-Input- Process - Product (CIPP) and Focus Group Discussion. Various activities were described based on observation and interview data. This study was conducted in three areas in Lampung Province, namely: East Lampung Regency, Pringsewu Regency, and Tanggamus Regency. Those areas are considered as a center the traditional fish processing with activities include fish salting, fish smoking, fish salty steamed, and fish fermentation. The research was conducted from July until September 2017. The result show, Generally, empowerment program for fisheries business players has been quite appropriate to their need, particularly in the sector of fish capture, aquaculture, and fish processing as seen from the high value in the aspect of context (appropriateness of program and problem, needs, and solving problem) and input (number and capability of extension officer, facility and infrastructure, fund). However, the value obtained in the aspect of process (socialization activity, assistance, appropriateness of implementation and plan) and product (target achievement, fulfillment of needs, and increasing income of fish processor) was still limited and need to be increased through intensive assistance by extension agent to achieve the objective of empowerment program of food self-sufficiency and welfare improvement of business players in fisheries sector.
\end{abstract}

Keywords: Empowerment; Extension Agent; Fish Processors; Business players

\section{Introduction}

Small-scale fisheries supply around 50\% of all global fish (Teh et al., 2011). The benefits of small-scale fisheries may be made clearer through an investigation of how seafood moves from the sea to the final consumers (Kittinger et al., 2015). In a developing country such as Indonesia, Sri Lanka, and Peru, the challenge for business players is mainly traditional fish processors of small-scale fisheries are to produce fish products with high quality to improve nutrition for all people. Food safety appears as a dynamic problem along with the development of human civilization as well as scientific and technological advances. Therefore, a system to control the production, processing, handling, 
transportation, storage, distribution, and serving of food is necessary. Fréon et al., (2014) mentioned in Peru some processors $(75 \%)$ have not considered safety standard in fish processing and fish products that meet consumer preference. Traditionally processed fish is a nutritionally and economically important commodity in many tropical developing countries. However, the major losses that occur are due to traditional processing methods, particularly the dried products that are processed by sun drying, salting and smoking. Salting is often used to enhance the quality and acceptability of naturally dried fish. In the case of oily fish, prolonged drying leads to bruising and rancidity (Ahmed, 2008). The smoking process has a minimal effect on muscle lipids, triglycerides and phospholipids and no significant changes were detected in the overall fatty acid composition. Salt can encourage oxidation of lipids in smoked. The antioxidant effects of some smoke compounds protect fat-soluble vitamins. However, in thick bodied fish, smoking can result in some loss of thiamine (2-25\%), niacin and riboflavin. Thus it affects the nutritional value of the fish, mainly by reducing the biological availability of proteins (Stroud, 1988) The typical smoked flavor results from a number of chemicals found in the smoke, mostly phenols. The use of high temperatures $\left(70-80^{\circ} \mathrm{C}\right)$ may lead to the formation of 3, 4, benzopyrene (Indicator of carcinogenicity). Furthermore, higher levels of polynuclear aromatic hydrocarbons (PAH) were detected in hot smoked fish (Ames GR 1990). Result of study by Soejono (2008) showed in Indonesia that fish processed through salting (salted fish) obtained an increase in value added of 29.6 percent. Traditional processing products are also favored by Indonesian society in general. Furthermore, study of Reswita (2014) indicated that traditional fish processing business is feasible to develop.

The capability of processors to ensure their products will meet the requirement of food safety and food health is essential. There is standard to be fulfilled in fish processing business; from a selection of raw material, determination of location and building, determination of tools and equipment for business, product processing in accordance with the quality standard, packaging, labeling, to distribution facility for products. Those aspects are technical skills that should be mastered by processors. As a business player, processors should also have the managerial skill to manage aspects of finance, marketing, human resource, environment, and cooperation to establish a partnership in order to develop the business. Excellent ability will result in high performance, thus increasing income and improving welfare. Lampung is number seventh the Province get the investment for fishery sector in Indonesia. However, traditional fish processing business in Bandar Lampung has not yet performed optimally and sustainably (Nazdan et al., 2017). Laisa et al., (2013) reported that processors participated in training and assistance provided to be able to produce the fish product with high quality since producing good product requires fresh fish as raw material. Hence, skill to determine raw materials is necessary for processors in running this business. Several results of a study (Tatuh et al., 2016, Uddin et al., 2011, Wijayanti and Lukitasari, 2018) mentioned that fish sold in some areas were contaminated with formalin. Thus, fish processors must have the technical skill to determine fresh raw materials to ensure that the product processed is safe to consume. The limitation of skill or knowledge of fish processor is the main problem in the traditional processor business, especially in Lampung Province. One of the efforts to develop skills should be mastered by fish processors can be done through empowerment programs by the government or NGO. Empowerment program that is designed and conducted well will increase the ability of processors to produce products with higher quality. However, in fact, processors in the coastal area of Lampung still run traditional fisheries business based on knowledge and skill acquired from previous generations. The cooperate between government, extension officer, fisheries in needed (Yanfika et al., 2019). Therefore, the purpose of this study is to evaluate the did empowerment program has been appropriated for the needs of traditional fisheries business.

\section{Methodology}

This study applied a descriptive qualitative method using the model of Context-Input-Process Product (CIPP) by considering the model direct target object of evaluation to the process and input to the result. In general, the period is divided into 3 stages: 1). Stage of preparation; this stage includes pre- 
observation and request for observation to the Fisheries Agency (Dinas Perikanan), 2). Stage of data collection; this stage includes all activities in the field such as field observation, interview, and Focus Group Discussion, 3). Stage of finishing; this stage includes data analysis base $d$ on data collected that is followed by the preparation of observation result according to the objective and researcher reveals an activity program that supports fisheries activity. Later, activities were described and explained according to observation data and interview data.

This study was conducted in three areas in Lampung Province: East Lampung Regency, Pringsewu Regency, and Tanggamus Regency. Those areas are considered as a center the traditional fish processing with activities like fish salting, fish smoking, fish steaming, and fish fermentation. The subjects of this study were the fish processor, fisherman, and fish farmer. Moreover, informants included head of Fisheries Agency, extension officer, fish processor group, fisherman group, and fish farmer group. The research was conducted from July to September 2017.

The elements for CIPP program evaluation for empowerment and extension of fisheries activity contain the followings:

1. FGD conducted in 2 groups (policymakers and processors).

2. Group of policymakers: Fisheries and Marine Agency, Fisheries Extension Officer, Higher education, and other agencies related to empowerment program. The number of participants for the policy group was 6 people.

3. Group of the processor from 4 types of business (smoking, salting, boiling and salting, and fermentation), while processing group had 8 people.

\section{Results and Discussions}

Empowerment program conducted by Fisheries and Marine Agency (Dinas Perikanan dan Kelautan) in Lampung Province covered three sectors such as fish capture, aquaculture, and fish processing and marketing. The ability or skill of fish processors can be developed through empowerment programs. This was supported by results of previous studies, which indicate that the program will increase a personal ability in performing his task, thus support of empowerment program is needed to improve a personal ability in running his business (Sharpe et al., 2016, Mosnaim et al., 2011, Hanssmann et al., 2010).

High-quality products produced by processor depend on the quality of raw materials supplied by fisherman and fish farmers. For example, people in Finland (Silvenius et al., 2017) preferred to consume salmon and research result showed that environmental impact affected the quality of aquaculture fish as raw materials. Therefore, empowerment program provided for fisherman and fish farmer is really important to produce a high-quality product, hence activities applied on those sectors will highly support processors to increase their ability to produce a product with high quality.

\subsection{Development of Fish Capture Sector}

The aim of fish capture empowerment program is to increase productivity of fish capture and improve fisherman welfare based on sustainable management of fish resource with goals of increasing production of fish capture (volume and value), increasing fisherman income, strengthening fisherman term of trade, and achieving those objectives and goals. The main activities performed include: (a) fish resource management; (b) coaching/training and development of fishing vessel, fishing gear, and fishing 
vessel monitoring; (c) development of fishing port infrastructure/facility; (d) fishing port management and operational; (e) efficient, organized, and sustainable fishing port; and (f) development of fish capture business and small-scale woman/fisherman empowerment. Programs concerning fish capture sector provided by Fisheries and Marine Agency of Tanggamus Regency include: (a) socialization of Fisherman Insurance Card (Kartu Asuransi Nelayan); this activity aims to provide knowledge and understanding to fisherman regarding the benefit of insurance, thus the target of this activity is fishermen in coastal area; (b) data input on fisherman household, this activity is aimed to completely record the data of all fisherman households; (c) provision of five units of fishing boat and 10 sets of fishing nets (ply) to fisherman group; (d) beach cleanup activity which targets community in coastal area and students; and (e) distribution of 5,000 fisherman insurance cards.

Fisheries and Animal Husbandry Agency of East Lampung Regency has several community empowerment programs/activities regarding fish resource monitoring and control, namely activity to develop fisheries self-initiative group. This activity is conducted to realize activities of coaching, monitoring and evaluation of monitoring and law enforcement by Babinsar (village non-commissioned officer), thus achieving society awareness on fisheries resource utilization.

According to the implementation result of CIPP model evaluation on fish capture program, it was found that the component of context, input, process, and product has already been well implemented as depicted by the high value of assessment from fish farmers, agency staff, and extension officer (Table 1).

Table 1. Program Evaluation of Fish Capture Sector

\begin{tabular}{lcc}
\hline Component of Assessment & Percentage & Value \\
\hline I. Context & & \\
a. Appropriateness of program and problem & 73.1 & High \\
b. Program is in accordance with the need & & \\
c. Solving problem & & \\
II. Input & 71.7 & High \\
a. Number of extension officer/assistant & & \\
b. Capability of extension officer/assistant & & \\
c. Facility and Infrastructure & & High \\
d. Fund & 70.9 & \\
III. Process & & \\
$\quad$ a. Socialization activity & & High \\
b. Assistance & & \\
c. Implementation of program according to the plan & & \\
IV. Product \\
a. Target achievement \\
b. Fulfilment of needs \\
c. Increasing income
\end{tabular}

The aspect of Context obtained percentage of above 70 percent since the program implemented in the field has been in accordance with assistance/coaching activity provided for fisherman group, particularly in solving problems faced by fishermen, such as provision of environmentally friendly fishing net and fishing boats of 5 GT (Gross Ton) to fisherman groups that will strengthen cooperation between groups, provision of insurance to fisherman so that they will be able to obtain safety guarantee whilst fishing.

The aspect of Input already good, however, several things need to be improved. Funds were available, both from APBD (Anggaran Pendapatan Belanja Daerah/ local government budget) or APBN (Anggaran Pendapatan Belanja Nasional/ national government budget). Moreover, the program provided 
has been appropriate to the program plan. Such as, TPI (Tempat Pelelangan Ikan/ fish auction site) office used as a gathering place for fisherman. Extension officers with Bachelor's degree at minimum were provided, and training was offered by the government to improve the quality of human resources who manage KUB (Kelompok Usaha Bersamal joint business group) and however not all KUB management participated in the training.

The aspect of Process was also good as shown by socialization activity of each program was conducted. Moreover, assistance activity performed by extension officers also going well considering the fact that fisheries extension officers became facilitator between other extension officer and other agencies/institutions in the field. Distribution of fishing nets and fishing boats of 5 GT capacity for village administrator to be used by fisherman in KUB, while fisherman insurance card was provided individually for fisherman. Gathering schedule was determined based on fisherman's activity, thus they could gather on time. Fishermen mostly shared and communicated their problem during the gathering. Later, extension officers and government staff will try to accommodate it in the form of a program. In the aspect of Product, coaching activity for group resulted in a good impact such as the increasing the number of fish capture. Government support in the form of fishing nets and fishing boats will increase the productivity of fishermen since they finally have the facility to expand their catching area. Increase in fisherman productivity will further increase fisherman income.

\subsection{Development of Aquaculture Sector}

Program of aquaculture development was conducted to increase aquaculture production with program target of an increase in production, productivity, and quality of aquaculture product. Several activities that supported this target included fish quality improvement, monitoring and assistance in the distribution of superior broodstock, provision of superior broodstock to hatchery, provision of fish seed to small-scale fish farmers, acceleration of CBIB (Cara Budidaya Ikan yang Baik/ Best Aquaculture Practices) certification, re-operating aquarium at the Local Government Office and Siger Tower, training of freshwater fish hatching, training of saltwater fish hatching, brackish water fish training, development of local hatchery unit, rehabilitation/development of government hatchery unit facility target, assistance for aquaculture partnerships, development of biofloc technology-based catfish farming, development of Demfarm, optimization of minapolitan areas, NRCP (National Residue Control Plan) audit by the European Union, guarantee for quality safety of aquaculture products, feed monitoring and control, fish disease and OIKB (Obat Ikan Kimia Biologi/ fish medicine), development and production of selfsufficient fish feed by fish farmers, development of ornamental fish culture, and survey of potential of Aquaculture Village.

(1) Development of aquaculture in open water.

(2) Assistance for PraseHATkan (program sertifikat hak atas tanah pembudidaya ikan/ program of land certification for fish farmer).

(3) Settlement of BLUD (Badan Layanan Umum Daerah/ local public service agency) asset in fisheries.

(4) Socialization and coaching on CBIB in regency/city.

Based on the evaluation result of the CIPP model on empowerment program for aquaculture development, it was found that the component of Context, Input, Process, and Product was significantly implemented. This finding is seen from the high value of assessment from a fish farmer, officer, and extension officer, as presented in Table 2. The aspect of Context obtained high percentage of higher than 60 percent by reason that the program implemented in the field has been appropriate to the coaching activity provided for fish farmer group (POKDAKAN: Kelompok Pembudidaya Ikan), particularly in solving problem faced by fish farmers, such as development of superior fish feed through the provision of certified broodstock and assistance for prasehatkan (land certification for fish farmer) program. 
Table 2. Program Evaluation for Aquaculture Sector

\begin{tabular}{llc}
\hline Component of Assessment & Percentage & Value \\
\hline I. Context & & \\
a. Appropriateness of program and problem & 70.0 & High \\
b. Program is in accordance with the need & & \\
c. Solving problem & & \\
II. Input & 6.40 & High \\
a. Number of extension officer/assistant & & \\
b. Capability of extension officer/assistant & & \\
c. Facility and Infrastructure & & \\
d. Fund & & High \\
III. Process & 67.1 & \\
a. Socialization activity & & \\
b. Assistance \\
c. Implementation of program according to the plan \\
IV. Product \\
a. Target achievement \\
b. Fulfilment of needs \\
c. Increasing income
\end{tabular}

The aspect of Input has well implemented, but there were several things to be improved. Funds were available, both from APBD (local government budget) or APBN (national government budget). Furthermore, the program provided has been appropriate to the plan, but class/training was still required to perform coaching or extension activity. Therefore, this aspect should be improved to ensure that fish farmers will obtain learning materials well. Besides, more extension officers are required since the number of extension officer was still limited. The addition of an extension officer will ease field activity, and training of technology for extension officer is necessary to increase the capability of extension officer. Process aspect was executed well as shown from the socialization program of each program implemented. Moreover, assistance activity was satisfactorily conducted by extension officer concerning the fact found in the field that most fish farmers were able to develop the training materials was obtained. This assistance activity raised the attention fisheries agency. In term of an aspect of the Product, coaching activity for group resulted in a good impact on skill improvement of fish hatching and fish growth technology in order to increase income and improve the welfare of fish farmer.

Program to optimize the management, marketing, and quality of fisheries production was conducted by producing high quality fisheries product with competitiveness in both domestic and international market and targeted to increase export value of fisheries product, increase volume of processing product, increase average fish consumption at national level, increase the value of nonconsumption product at level of big seller, and increase investment value in processing and marketing of fisheries product. To achieve this goal, the main activities carried out included provincial cooking contest of Lampung typical food made of fish, optimization of agribusiness terminal, statistical consolidation and validation of P2HP (Badan Pengelolaan dan Pemasaran Hasil Perikanan), technology adoption of quality assurance and food safety of fishery products for export and local consumption, control and monitoring of food safety and quality of fisheries products in local market and SMEs (small and medium enterprises / Usaha Kecil Menengah: UKM) that run fisheries processing, capacity improvement of LPPMHP (Laboratorium Pembinaan dan Pengujian Mutu Hasil Perikanan / Laboratory of Development and Quality Testing of Fisheries Products) as testing laboratory of UPTD LPPMHP (Technical Implementation Unit of LPPMPH) in order to maintain accreditation of ISO 17025 and 17020, processing of fisheries products, coaching for processing center, monitoring and evaluation of PUMP P2HP (Program Pengembangan Usaha Mina Pedesaan Pengolahan dan Pemasaran Hasil Perikanan/ Rural Business Development Program for Processing and Marketing of Fishery Products), 
appreciation/training on local quality development, facilitating the application of halal certification for fisheries products, provision of cold chain facility, and provision of craft equipment.

\subsection{Analysis of Program/Activity in Fish Processing and Marketing Sector}

According to the evaluation result of CIPP model implementation on fish processing and marketing program, it was found that the components of context, input, and process were appropriate as seen from the assessment value that was higher than 50\%, while the component of product has not yet appropriate since the value obtained was lower than $50 \%$. This outcome was caused by the fact that program plan has been already in accordance with the needs and problems that included: increase of processor income and knowledge improvement regarding various fish products such as meatball, fish nugget, and crab processing, thus processor was able to develop their business besides the traditional processing one (fish salting, fish salting and boiling, fish smoking, fish smoking, and fish fermentation) to support the program of GEMARIKAN (gemar makan ikan, let's eat fish). Moreover, this program was considered to improve the ability of processors in applying the technology conveyed related to the product packaging.

It was expected that aspect of Context would be able to solve the problem, and program implementation was already appropriate to the availability of natural resource and human resource obtained. Moreover, the component of the process was also adjusted to the useful model following the condition of the target. However, in term of context and input, couching for traditional processors related to technology should also put into consideration to prove that it is possible for traditional processing business to gain higher selling value and is accepted by the wider community.

Table 3. Program evaluation for Fish processing and marketing sector

\begin{tabular}{|c|c|c|}
\hline Component of Assessment & Percentage & Value \\
\hline $\begin{array}{l}\text { I. Context } \\
\text { a. Appropriateness of program and problem } \\
\text { b. Program is in accordance with the need } \\
\text { c. Solving problem }\end{array}$ & 61.8 & High \\
\hline $\begin{array}{l}\text { II. Input } \\
\text { a. Number of extension officer/assistant } \\
\text { b. Capability of extension officer/assistant } \\
\text { c. Facility and Infrastructure } \\
\text { d. Fund }\end{array}$ & 67.8 & High \\
\hline $\begin{array}{l}\text { III. Process } \\
\text { a. Socialization activity } \\
\text { b. Assistance } \\
\text { c. Implementation of program according to the plan }\end{array}$ & 58.8 & Medium \\
\hline $\begin{array}{l}\text { IV. Product } \\
\text { a. Target achievement } \\
\text { b. Fulfilment of needs } \\
\text { c. Increasing income }\end{array}$ & 48.7 & Medium \\
\hline
\end{tabular}

Aspects that required attention included process and product since not all processors were able to apply the knowledge and technology obtained from activity in their business. There were still processors who have not obtained extension service. Moreover, training frequency needs to be increased because it was not able to improve the skill and income of processors. Some processors have not participated in the training program because they still focused on their existing business. Therefore, continuous assistance is necessary to improve the knowledge and skill of processors; thus, they will have the ability to run the business independently. Program of evaluation is presented in Table 3. 
Result of CIPP analysis on program/activity conducted in fisheries and marine sector in three regencies of Lampung province showed that the sector of fish capture and aquaculture have been appropriate to the needs of a target, while the sector of product processing and marketing still have to be improved. Facts obtained in the field for the last three years indicated that activities/programs were always offered and provided for processors, yet there was a particular activity like a fish cooking competition that was intended to support the program "Gemar Memasyarakatkan Makan Ikan." However, not all processors could join this activity since there was a selection for participants. The competition was only for processors who were considered to have cooking skill. Furthermore, there was still government support in the form of processing equipment such as icebox and fish smoking equipment three years ago. Result of the interview showed that the government focused more on the sector of fish capture and aquaculture concerning the agency budget allocation. Based on Figure 6, the component of context, input, process, and product in the sector of fish capture and aquaculture has been applied well as confirmed by the assessment value from activity target, extension officer, and staff of fisheries agency.

Traditional processors, particularly those who run business in fish salting/boiling or pindang, smoking, and fermentation, felt that the program or activity has not yet optimally conducted as there were too few programs. Thus, fisheries agency for fish processing unit currently focuses on fish processed to nugget, meatball, fish pudding, sustainable crab processing, and not all processors have been able to produce those products. Also, processors still conduct traditional processing technic (fish salting, fish fermentation, fish steam with salty water, and fish smoking).

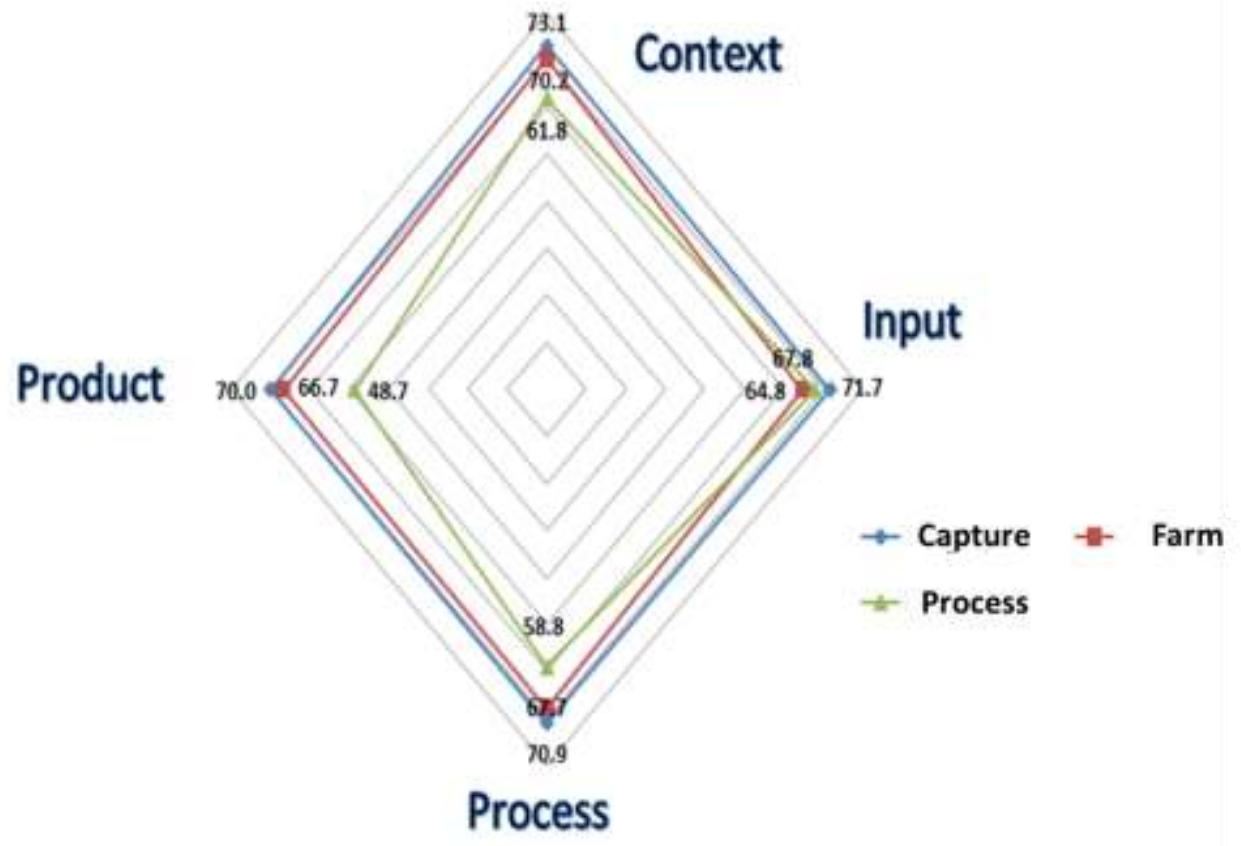

Figure 1. CIPP analysis of fisheries extension program

Fisherman and fish farmer considered the activities performed have been appropriate to their needs and were able to provide a solution to their problem. Moreover, programs in the form of activity and support have trained participants to develop cooperation between fisherman and fish farmer, to be hardworking, fisherman, fish farmer, and processor applied the technology obtained, either it was environmentally-friendly fishing gear or fish farming of catfish, Mozambique tilapia (mujair), gourami, and vannamei shrimp. 
The group highly requires the support of empowerment program for business players in the fisheries sector of fisherman, fish farmer, and fish processor in order to improve knowledge and skill in running their business, thus affecting production with high quantity and quality to increase income and improve the welfare of business players in Lampung Province. Londa (2014) reported the increasing community income through Empowerment Program in Lolah II Village, District of Tombariri, Regency of Minahasa was carried out in several empowerment programs such as business capital loan through the national program of rural community empowerment. It was also explained by Barombo (2012) that the empowerment program did not only increase income but also affected social life within the community.

\section{Conclusions}

In general, empowerment program for fisheries business players has been entirely appropriate to their need, particularly in the sector of fish capture, aquaculture, and fish processing as seen from the high value in the aspect of context (appropriateness of program and problem, needs, and solving problem) and input (number and capability of extension officer, facility and infrastructure, fund). However, the value obtained in the aspect of process (socialization activity, assistance, appropriateness of implementation and plan) and product (target achievement, fulfillment of needs, and increasing income of fish processor) was still limited and need to be increased through more intensive assistance to achieve the objective of empowerment program, those are self-sufficiency and welfare improvement of business players in the fisheries sector.

\section{References}

Ahmed, A.A. (2008). Post-Harvest Losses of Fish in Developing Countries. Nutrition and Health.19: 273-287.

Ames GR (1990) The kinds and levels of post-harvest losses in African inland fisheries. Proceedings of the Symposium on Post-Harvest Fish Technology, FAO, Rome, Italy. pp: 1-10.

Barombo, A. (2012). Pemberdayaan Masyarakat Melalui Koperasi Credit Union (CU) Studi Pada CU Khatulistiwa Bakti Pontianak. Jurnal Program Studi Ilmu Sosial. (In Indonesia).

Fréon, P., Sueiro, J. C., Iriarte, F., Miro Evar, O. F., Landa, Y., Mittaine, J. F., \& Bouchon, M. (2014). Harvesting for food versus feed: A review of Peruvian fisheries in a global context. Reviews in Fish Biology and Fisheries. 24:381-398.

Hanssmann, C., Morrison, D., Russian, E., Shiu-Thornton, S., \& Bowen, D. (2010). A Community-Based Program Evaluation of Community Competency Trainings. Journal of the Association of Nurses in AIDS Care. 21: 240-255.

Kittinger, J.N., et al., 2015. From Reef to Table: Social and Ecological Factors Affecting Coral Reef Fisheries, Artisanal Seafood Supply Chains, And Seafood Security. Plos One.10: e0123856.

Laisa, D. D., Sayekti, W. D., \& Nugraha, A. (2013). Analisis Harga Pokok Produksi Dan Strategi Pengembangan Industri Pengolahan Ikan Teri Nasi Kering Di Pulau Pasaran Kecamatan Teluk Betung Barat Kota Bandar Lampung. Jurnal Ilmu Ilmu Agribisnis. 1: 111-117.

Tulusan., F. M. G. \& Londa., V. Y. (2014). Peningkatan Pendapatan Masyarakat Melalui Program Pemberdayaan Di Desa Lolah II Kecamatan Tombariri Kabupaten Minahasa. Jurnal LPPM Bidang EkoSosBudKum. 1:92-105. 
Mosnaim, G. S., Li, H., Damitz, M., Sharp, L. K., Li, Z., Talati, A., \& Powell, L. H. (2011). Evaluation of the Fight Asthma Now (FAN) program to improve asthma knowledge in urban youth and teenagers. Journal of Allergy and Clinical Immunology. 125: AB59.

Nazdan, N., Setiawan, B., \& Sukandar, D. (2017). Analisis Potensi Dan Pengelolaan Perikanan Dalam Perspektif Ketahanan Pangan Di Wilayah Pesisir Kabupaten Lampung Barat. Jurnal Gizi Dan Pangan. 3: 149-155.

Reswita. (2014). Kelayakan usaha pengolah ikan asin di Kelurahan Sumber Jaya Kecamatan Kampung Melayu Kota Bengkulu. AGRISEP. 14: 247-225.

Sharpe, E. K., Forrester, S., \& Mandigo, J. (2016). Engaging Community Providers to Create More Active After-School Environments: Results from The Ontario Catch Kids Club Implementation Project. Journal of Physical Activity and Health. 8: 26-31.

Silvenius, F., Grönroos, J., Kankainen, M., Kurppa, S., Mäkinen, T., \& Vielma, J. (2017). Impact of Feed Raw Material to Climate and Eutrophication Impacts of Finnish Rainbow Trout Farming and Comparisons on Climate Impact and Eutrophication Between Farmed and Wild Fish. Journal of Cleaner Production. 164: 1467-1473.

Soejono, D. (2008). Pola Pengembangan Agroindustri Berbasis Perikanan Laut Di Kecamatan Puger Kabupaten Jember. Journal of Social and Agricultural Economics. 2: 30-37.

Stroud, G.D. (1988) A technical and economical appraisal of artisanal smoking ovens in Ghana. Proceedings of FAO Expert Consultation on Fish Technology in Africa. Proceedings of FAO Expert Consultation on Planning and Development.Report No: 400.

Tatuh, H. A., Rorong, J., \& Sudewi, S. (2016). Analisis Kandungan Formalin Pada Berbagai Jenis Ikan Di Kota Manado. PHARMACON Jurnal Ilmiah Farmasi. 5: 162-167.

Teh, L.S.L., Teh, L.C.L., Sumaila, U.R., 2011. Quantifying the Overlooked Socio-Economiccontribution of Small-Scale Fisheries in Sabah, Malaysia. Fisheries Research. 110: 450-458.

Uddin, R., Wahid, M. I., Jesmeen, T., Huda, N. H., \& Sutradhar, K. B. (2011). Detection of formalin in fish samples collected from Dhaka city, Bangladesh. Stamford Journal of Pharmaceutical Sciences. 4: 49-52.

Yanfika, H., Listiana, I., Mutolib, A and Rahmat, A. (2019). Linkages between Extension Institutions and Stakeholders in the Development of Sustainable Fisheries in Lampung Province. Journal of Physics: Conference Series. 1155 (1), 012014.

Wijayanti, N. S., \& Lukitasari, M. (2018). Analisis Kandungan Formalin dan Uji Organoleptik Ikan Asin yang Beredar di Pasar Besar Madiun. Florea : Jurnal Biologi Dan Pembelajarannya. 3: 59-64.

\section{Copyrights}

Copyright for this article is retained by the author(s), with first publication rights granted to the journal. This is an open-access article distributed under the terms and conditions of the Creative Commons Attribution license (http://creativecommons.org/licenses/by/4.0/). 